\title{
Setting the Policy Agenda for Combating the Abuse of New Psychoactive Substances in the Republic of Croatia
}

\author{
Dijana Jerković \\ Government of the Republic of Croatia, Office for Combating Drugs Abuse \\ Prof. dr. sc. Zdravko Petak \\ Faculty of Political Science University of Zagreb
}

\begin{abstract}
Although the Early Warning System on New Psychoactive Substances in the Republic of Croatia was established in 2007, the phenomenon of new psychoactive substances only recently began garnering attention. This surge in attention is largely due to reports from other EU countries on intoxications and deaths connected to these, as well as the increased availability of these substances in specialized shops ("smart shops") and on the internet.

This paper demonstrates the agenda-setting process in relation to the policy for combating new psychoactive substances abuse in Croatia by using the phase model or the policy-cycle model of policy-making process. The agenda-setting phase is characterized by a presentation of a specific problem as an important public policy issue; therefore, the aim of this paper is to discuss activities, circumstances and actors that are important for agenda setting of the policy for combating new psychoactive substances in Croatia.
\end{abstract}

Keywords: public policy, policy agenda-setting, new psychoactive substances, Early Warning System on New Psychoactive Substances

\section{Introduction}

The past two decades have seen a rapid rise in discovery and use of new psychoactive substances in Europe and more recently in Croatia. These substances are not on the list of the UN Single Convention on Narcotic Drugs of 1961 nor are they found in the UN Convention on Psychotropic Substances of 1971, but they may pose a public health risk just as the already banned substances do (Council of the European Union, 2005; Jerković, 2016). These substances are compounds that mimic the effects of the standard drugs, but also include new ways of abuse of already known substances (Council of the European Union, 2005; UNODC, 2015), which indicates that there is a need to provide an adequate response in the form of initiating a systematic policy.

Understanding the complexity of the process by which a certain societal problem becomes the topic of public policy also demands an understanding of the context in which the creation of public policy begins (Young, Borland and Coghill, 2010). Accordingly, the main purpose of this paper is to note the processes that have led to the setting of policy of preventing psychoactive substance abuse and the related implementation programs. This process will be studied by means studying the actors, activities and circumstances (context) that have defined the process of placing this policy on the political decision-makers' agenda. 
It is necessary to note that the agenda-setting phase is an analytical category, and not something that can be circumscribed in a chronological description. Directing the focus of research on this phase of policy-making suggests that the events that would follow in the later stages, those of formulating, legitimizing, implementing, and evaluating the policy, are crucially defined in that first step. The way in which the decision-makers' collective attention is turned to particular social problems is at the very core of defining the policy agenda-setting. This also affects further development and the changes of a particular policy (Green-Pedersen and Mortensen, 2013, 170).

As the topic of new psychoactive substances is generally approached from the point of view of public health and the legislative process, this paper makes the contribution of focusing on the subject matter from the perspective of public policy creation. This approach seeks to contribute to a wider recognition of this problem from the standpoint of various stakeholders, with the aim of improving the existing practice of shaping this policy. There has been relatively little research that deals with the substance abuse prevention policy as an example of agenda-setting and the process of policy-making, or as an example of policy implementation programs. One of the examples is found in the application of agenda-setting models as developed in the work by Roger Cobb and associates, who were working on research related to substance-abuse prevention policy in the US during the 1970s and 1980s (Sharp, 1992).

\section{New psychoactive substances abuse in Croatia}

The problem of new psychoactive substances in Croatia had not been recognized as such nor was it the topic of public policy for a long time, as the incidence of such substance abuse was only sporadic during the 2000s, as was the identification of new psychoactive compounds. Nevertheless, the research on addictive substance abuse in various target groups has in recent years indicated their presence and abuse. For example, the second Substance Abuse in the General Population of Croatia study, conducted on a representative sample of Croatian citizens aged 15 to 64 ( $N=4992)$, found that the life prevalence of use of any new psychoactive substance is $2.7 \%$ among the whole surveyed population, while it is somewhat higher among those aged 15 to 34 , at $5.4 \%$ (Glavak Tkalić, Miletić and Maričić, 2016). A 2011 ( $N=1330)$ and 2013 ( $\mathrm{N}=1035)$ study by Forum.hr (an online discussion forum) on availability and use of these substances on a convenience sample of youths ( $90 \%$ of respondents were aged 18 to 40 ), suggested that the respondents were largely acquainted with the new trends in psychoactive substance abuse and that they have information on how these new drugs can be acquired and abused (Kranželić and Jerković, 2012; Kranželić and Doležal, 2013).

Similar results were found in the June 2014 Flash Eurobarometer, conducted on a sample of 13128 EU citizens, aged 15 to 24 . It found that $8 \%$ of all respondents had consumed at least one new psychoactive substance, while the figure was 7\% for Croatian nationals (European Commission, 2014).

New psychoactive substances are also available among students in higher education, as indicated by the Croatian Students' Quality of Living survey ( $N=1880$; Kovčo Vukadin, 2014). Further, a study conducted on a quota sample (with regard to sex and area of study) of 438 students (37.9\% men, $62.1 \%$ women) in their first two years of undergraduate study who had been living in university 
dormitories found that $3 \%$ of them had at least once consumed synthetic cannabinoids, with no statistically significant difference between men and women (Jerković, 2015).

The prevalence of new psychoactive substance abuse seems somewhat higher among high-school students. The latest results of the ESPAD survey among 16-year-olds in 35 European countries suggested that the Croatian students $(\mathrm{N}=2558)$ are above European average in new psychoactive substance abuse, as $7 \%$ of respondents noted that they had at least once tried a new psychoactive substance (Kraus et al., 2016). Further, research among clients of a damage reduction program, who are one of the risk groups, indicated that these substances are not popular among those in Croatia that engage in intravenous opiate abuse, and who are part of the above-mentioned programs (Doležal, 2012).

It appears that the new psychoactive substance abuse in Croatia is at this point still recreational. However, even though these are low levels of abuse prevalence, the potential public health risks they bring are non-negligible, particularly if one takes into account the lack of information regarding the effects of these substances.

\section{Agenda-setting and the process of public policy creation}

The most common approach to public policy research places the process of their creation at the center (Colebatch, 2004; Hill, 2010; Cairney, 2013). This is a rationalist understanding of the process of policy-making in which the forming, implementation, and evaluation of public policy are conceived of as part of a cycle of problem-solving, with a series of sequences that vary in terms of the number of actors and causal logic. The identified number of phases in a thusly understood process varies from author to author. Harold Laswell, the founder of academic study of public policy, suggested that the process consists of seven distinct phases, from the starting phase of gathering information (intelligence), to evaluation as the final stage. In Croatian literature, Grdešić (1995) discerns various ways of layering the policy cycle. The contemporary literature on public policy most commonly uses a policy cycle model consisting of five or six separate phases: agenda-setting, formulation, legitimation, implementation, and evaluation, with this last phase sometimes divided into the pure evaluation phase and making a decision on whether to continue the implementation of policy or not (Hill, 2010; Hogwood and Gunn,1984; Howlett, Ramesh and Perl, 2009).

Within this conceptual framework, public policy is understood as a collective choice of policy for a community, whereby the establishment, development, and implementation of policy in a particular sector is intended to influence the solving of a problem that the community is facing. By using analytical tools based on the demarcation of processes of policy-making and implementation, scholars seek to find regularities in the particular sequences of policy-making, ways of moving from one stage to the next, or the number of actors that take part in the process (Petak, 2007; Petak, 2008). In practice, however, there is a significant divergence from this model, which has been a frequent topic of critique. The opponents sought to show that the formation of policy does not take place in clear and linear succession of phases. Regardless of the range of criticism that may be levied at this understanding of process of creating public policy, the standard model is widely accepted in academic work. Peter John, a British scholar of the topic, suggested the perhaps key reason why the model is still widely accepted: the heuristic of phases has brought about a sort of 
order in the study of public policy, but it has also separated public policy as an academic discipline from the legalistic study of institutions as found in legal studies (John ,1998).

The agenda-setting phase is perhaps the most critical one in the policy-making cycle, as the events in this phase have a decisive influence on the remainder of the cycle and its core outcomes. This phase is characterized by the recognition of a phenomenon as a public policy problem which demands government's further attention (Dearing and Rogers, 1996; Jones and Baumgartner, 2005; Baumgartner, Green-Pedersen and Jones, 2006; Princen, 2009). The public policy agenda and the way it is determined are not referring just to a set of societal problems, but also to understanding the source of these problems and the symbols related to the agenda and the solutions of these problems. In other words, if the institutions of authority are to act, a particular societal phenomenon ought to be conceived of as unsatisfactory, changeable, socially constructed as a collective problem, and recognized as a priority (Petek, 2012; Petek, 2014, 54-55). In this way, a societal problem becomes a public policy problem, i.e. it is placed on the agenda of political decision-making.

\section{Types and characteristics of public policy agenda-setting}

In a time of increasing change, globalization, and individualization, public policy does not simply occur as a result of decision-making based on authority, but rather as a consequence of a process in which the problems public policy tackles are recognized by the wider public. As a rule, theory of public policy is directed towards three analytical dimensions, those of actors, institutions, and ideas, which makes public policy research a demanding task, as it takes into account both the state actors and the social actors included in the decision-making process (Hajer, 2003). When it comes to researching the actors' activities and their influence on the development of public policy it is important to research not just that actor which makes authoritative decisions (government), but also those actors who take part in creating policy based on their interest in said policy (stakeholders). Accordingly, those actors which take part in shaping public policy on the basis of governmental authority can be termed vertical actors, while those that take part on the grounds of cooperation and negotiation on policy can be termed horizontal actors in public policy (Colebatch, 2004).

One of the most important researchers in this field of study, American political scientist John Kingdon, notes in his classical book Agendas, Alternatives and Public Policies (Kingdon, 1984) that the public policy agenda changes need to be considered as having two separate aspects. The first one refers to the indicators of the observed problem, based on which the size and need for appropriate action faced by the community can try to be assessed. The second aspect which may affect change of agenda refers to the different types of focusing events that point the public attention to a particular problem in the society. This refers to everything that contributes to the strengthening of attention afforded to an important issue, the solution to which must be faced by the community. Additionally, this increase in attention creates a situation which may lead to a change in policy in the given policy area. This aspect of agenda-setting has been the topic of a wide literature over the past several decades (Birkland and DeYoung, 2013) and is considered to be one of the valid theoretical approaches to considering the setting of public policy programs. Public policy researchers who take this approach as the basis of their work differentiate between those public policy areas that do not see much influence or interest of the general public and those 
where there is a great interest on the part of the general public. This is a differentiation that has been put forward by the famous public policy theoretician Peter May, distinguishing between "two different political environments - policies with and without publics" (May, 1990).

In contrast to these studies of agenda-setting, an alternative, post-positivist approach was gradually being developed, placing an emphasis on the subjective construction of public policy problems, and the roles of actors and paradigms. These are various interpretative approaches which have pointed out a series of relevant questions that affect the way public policy programs and agendas are determined. This is primarily work that provides a new framing for an existing issue, as particularly exemplified by the classical study by famous public policy theorists Schneider and Ingram (1993). Additionally, other research has suggested the importance of types of narratives, symbols, and language that the policy advocates use in the process of public policy agenda-setting. Namely, the ideas held by the actors in public policy have a significant impact on the decision-making process, which means that traditions, convictions, and attitudes regarding the world and society affect the way in which individuals interpret their interests (Flathman, 1966, in Howlett, Ramesh and Perl, 2009). Ideologies are particularly important, as they represent the core beliefs and causal explanations that serve as guides for various activities, for ways of defining problems, and criteria for limiting the range of answers that are given to the challenges of particular policies. Taking all of this into account, one of the most famous theorists of public policy, Deborah Stone, notes that setting the agenda includes the construction of narratives concerning the causes of a particular problem related to a policy (Stone, 2012).

The attempts to provide better and more systematic combinations of some above identified core variables and a more wide-ranging and empirically accurate agenda-setting theory have resulted in the development of multivariate models. These models attempt to grasp the relationship between societal, institutional, political, and economic conditions in the process of determining the policy agenda. They are based on the assumption that the agenda is affected by socio-economic and physical environment, distribution of power in society, dominant ideas and ideologies, institutional framework of government, and the decision-making process (Mazmanian and Sabatier, 1980). It is precisely the assumption of causal diversity in understanding the problem of placing public policy on the agenda of political decision-making that represents the key strength of this model.

Further, one of the founders of rational choice theory, Anthony Downs (1972), proposed in the 1970s the concept of issue-attention cycle, which suggests that the process of public policy creation is often focused on the problem which is in the public eye and which thus encourages the public demands for governmental activity, thus allowing for introduction of innovative public policy.

In their classical piece on determining the agenda of public policy, which also represented a sort of turning point in the development of taxonomies of public policy agendas, Cobb and Elder (1972, in Howlett, Ramesh and Perl, 2009) suggested a differentiation of systemic, institutional, and daily decision-making orders. The first entails all matters that the policy creating actors perceive as problems of the community; the second refers to all matters that those in power find important and engage with; the third refers to situations of making decisions concerning real implementation of public policy. This was a significant contribution to the understanding of agenda-setting phases, as these types appeared in academic literature for the first time. The systemic agenda (informal) 
consists of topics which have been recognized by the policy community and which require governmental action. These are most often related to the societal agenda, which includes discussion on individual or social problems, such as crime or healthcare. However, only a small portion of topics on the systemic agenda receive adequate attention from the government (Howlett, Ramesh and Perl, 2009). Only when a government recognizes a certain problem can a phenomenon be said to be on the institutional (formal) agenda. The process through which a policy problem moves from informal to institutional agenda-setting consists of four inter-phases (Cobb, Ross and Ross, 1976) - initializing discussion, specifying the possible solutions, expanding support for the recognition of the problem, and, if all of the above were successful, introducing a policy problem to the political decision-making agenda. In order to gain an insight into the broader image of the problem, one needs to link these agenda types with the context (Howlett, Ramesh and Perl, 2009).

The importance of context was recognized in mid-1980s by John Kingdon (1984), when introducing the concept of "policy window". This idea refers to the construction and the use of possibilities of determining the agenda, while taking into account the three streams that placing a policy on the agenda depends on. These three streams are the problem stream, policy stream, and the political stream. The development of the problem assumes a perception of the phenomenon as a question related to a particular policy which demands a political response. The role of experts who research the policy problem and offer alternatives for its solutions is particularly important here. Finally, the political response is affected by the mood of the nation, administrative or legislative turns, and interest group activities. These components may exist independently of one another up until the moment of opening of the policy window, in which the problems, solutions, and possible courses of action interact (Kingdon, 1984, 174-180).

In order to understand the dynamics that lead to the overlap of the three streams, it is important to note the research that has been encouraged since the 1990s by American political scientists Frank Baumgartner and Bryan Jones (1991). In that context, the concept of policy subsystems should be noted, which the academic literature uses to refer to relatively stable groups of "actors who have an adequate level of knowledge regarding a problem area or the available resources, which enables them to take part in the process of shaping alternative courses of action, in order to consider the questions that arose in the agenda-setting phase" (Howlett, Ramesh and Perl, 2009, 12). In line with this, there are subsystems which bear dominantly monopolistic or competitive characteristics. In the first group, there is a set pattern of debate concerning a particular policy or its key aspects, and the institutional patterns within which this takes place are set and not prone to change. On the other hand, the competitive systems introduce elements of debate and argument, enable the alteration of key frameworks and policy discourses, and allow for a change in policy. These subsystems can be linked to the basic characteristics of ideas concerning public policy, i.e. to the matter of old or new ideas.

By linking together these two kinds of public policy subsystems and the two kinds of ideas on public policy, we reach four basic ways of setting the public policy agenda (Howlett, Ramesh and Perl, 2009, 106-107): 1) status quo, which is based on the monopolistic system and old ideas; 2) contestation, based on a competitive system and old ideas; 3 ) redefining, based on a monopolistic system and new ideas; and 4) redefining, based on a competitive subsystem and new ideas. The key variable that changes in these four models is the way that the image of the public policy 
problem is presented in the debates within subsystem or in public. In that context, it is important to differentiate between policies by the extent of public influence, as previously noted by May (1990). Baumgartner and Jones (1991) also find that some problems that the community is facing are predominantly portrayed as technical matters, and their resolution is placed in the hands of experts who dominate the related policy-making process. On the other hand, matters that have a broader social and political relevance demand the participation of the broader public and the inclusion of a greater number of interested individuals and groups. Thus, in order to understand the debates concerning the way that a particular policy problem is portrayed, one needs to understand the competition of "individuals and groups that hold power in the existing subsystems and those who aim to affect these subsystems by using external influence" (Howlett, Ramesh and Perl, 2009, 106).

Starting from these claims, Baumgartner and Jones (1993) developed their variation of the punctuated equilibrium model, which has become one of the most influential approaches to understanding the dynamics of placing public policy on the agenda of political decision-making (Baumgartner and Jones, 2009). This is an approach that begins with the idea that the process of policy-making is followed by relatively long periods of set and balanced patterns of behavior and institutional arrangement, which are then followed by abrupt, sudden change. The forces of maintaining the status quo are predominantly affected by the negative feedback processes, supported by various mechanisms of agenda denial. On the other hand, the possibility of interrupting the established balances is brought on by the positive feedback processes, which cause sudden change in the observed public policy. Following this change, a state of long-term stability is again established, allowing for incremental change only. In their later work Baumgartner and Jones admit that there is a certain similarity between their model and that of advocacy coalitions, which was developed at the same time by Paul Sabatier and Hank Jenkins-Smith (1993). However, there are also significant differences between the two models. While the advocacy coalitions framework is based primarily on systems of values and convictions, the punctuated equilibrium model is based on allocation, i.e. redirection of attention to particular issues as conducted by the policy-makers. This redirection of attention happens, the authors suggest, in a disjointed and messy, almost episodic way, causing intense and sudden change (Jones and Baumgartner, 2012, 4).

Unlike these approaches, which point out the importance of sudden changes in the way that public policy is made, there are also those whose authors suggest the opposite. Dutch theorist Marteen Hajer (2003) notes that the changeable context of policy-making needs to take into account the challenges related to the dispersed ordering of decision-making, the relationship between policy-making and political decision-making, the need to question the standard views of participation and democratic leadership, changeable role of classic scholarly expertise, and the broad context in which policy is made. The assumed political context of policy analysis consists of a minimum of three elements: political decision-making, knowledge, and intervention (Hajer, 2003). In other words, Hajer thinks that a stable political order represents a precondition for policy-making, that knowledge needs to be scientifically grounded even though it is produced for the purpose of political decision-making, and that intervention is, as a rule, problem-oriented and aims to change the existing state. 


\section{Setting the agenda for the policy of combatting new psychoactive substance abuse in Croatia}

The remainder of the paper provides an overview of the programs and the agenda for policy of combatting the abuse of new psychoactive substances in Croatia, and will attempt to identify three of Hajer's (2003) elements: political decision-making, knowledge, and intervention. In order to better understand the state of this policy, the actor network theory will be applied.

Determining the agenda for the policy of combatting the abuse of new psychoactive substances is a process that lasts multiple years and which is marked by different actors, primarily those at the European level. From the beginning of the 1990s, European Union countries have seen the appearance of so-called designer drugs, most commonly psychotropic substances similar to amphetamines and MDMA. Their appearance has brought about questions regarding potential health risks and problems that might occur if these substances are not under legal control in some, but not all member states. The response to this situation was found in the potential for the exchange of information and implementation of risk assessments and potential control mechanisms across the EU (EMCDDA, 2007). This resulted in the passing of Joint Action concerning the information exchange, risk assessment and control of new synthetic drugs (Council of the European Union, 1997), which has served as the foundation for the development of the early-warning mechanism. It should be noted that the definition of new synthetic drugs included those substances that had limited therapeutic value, which were at that time not on the list of the UN Convention on Psychotropic Substances of 1971, and which pose a serious risk to public health, as the substances on List I and List II of the Convention do. The adjective "new" was not just used to refer to newly created substances, but also included the new forms of abuse of already known substances (EMCDDA, 2007). The 2005/387/JHA decision of the Council on the exchange of information, risk-assessment, and control of new psychoactive substances (Council of the European Union, 2005) expanded this mechanism to all new psychoactive substances and set up the EU Early-Warning System for the appearance of new substances. At the EU level, the major factors responsible for managing the system European Monitoring Centre for Drugs and Drug Addiction - EMCDDA and Europol, and the key partners are the national contact points as parts of the European information network on drugs and drug addiction (Reitox - Réseau Européen d 'Information sur les Drogues et les Toxicomanies') which forms the human and informational connection among national information systems.

Croatia was not an EU member at the time when the Joint Action and the Council decision were adopted, but it did begin to make institutional changes in 2002, with the founding of the Office for Combatting Drug Abuse (Regulation on Founding of the Office for Combatting Drug Abuse, NN 18/2002, 12/2005, 111/2006, 19/2010, 36/2012, 130/2012, based on the Combatting Drug Abuse Act, NN 107/2001, 87/2002, 163/2003, 141/2004, 40/2007, 149/2009, 84/2011). In 2003, the Office began informal cooperation with EMCDDA1, and, in 2006, with the Section of the National Information Unit for Drugs and Matters of International Cooperation (NN 111/2006), which is the national contact point for EMCDDA. The foundation for the development of the policy for combatting new psychoactive substances in Croatia was set by the National strategy for preventing drug abuse in the Republic of Croatia for 2006 -2012 (NN 147/2005) and the National strategy for preventing drug abuse in the Republic of Croatia for 2012 - 2017 (NN 122/2012) as key documents

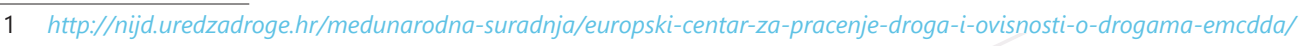


in the combatting drug abuse policy. These strategic documents, the latter in particular, foresee the creation of a system for rapid information exchange on matters of production, trade, abuse, and risks of new psychoactive substances, in order to prevent their adverse effects. This was followed by the introduction of the Protocol on the Early-Warning System, that the Government of the Republic of Croatia adopted in 2007. An agreement between Croatia and the EU was signed in January 2010, which allowed for Croatia's participation in the European Monitoring Centre for Drugs and Drug Addiction, and this was was confirmed by the Croatian parliament (Sabor) in March 2013, when it adopted the Act on confirming the Agreement between the Republic of Croatia and the European Union on the participation of the Republic of Croatia in the work of the European Monitoring Centre for Drugs and Drug Addiction (NN 03/2013, International agreements). This meant that the Agreement provisions became part of Croatia's internal legal order, per Constitution of the Republic of Croatia (NN 56/1990, 135/1997, 113/2000, 28/2001, 76/2010, 05/2014). These legislative procedures and executive actors are the political decision-makers, i.e. one of the preconditions for the creation of public policy, which Hajer (2003) also refers to as the political order.

The use of knowledge produced by the academic disciplines that deal with public policy discourses can be varied and basically refers to the different levels of complexity of indicators of public policy (Kustec Lipicer, 2008). The increase in knowledge represents the second important component of policy-making (Hajer, 2003). This component is particularly important for understanding the functioning of the early warning system in the case of appearance of new substances. Given that a real threat of new psychoactive substances did not exist in Croatia in the timeframe under consideration, a wider recognition of this problem in society only appeared more recently, with growing incidence of poisoning and mortality related to abuse of new psychoactive substances in EU member states, suspicious cases of poisoning in Croatia, and a growing interest of the media in the issue of new drugs. At the European level, information concerning the newly identified psychoactive substances through the EU Early Warning System show that, for example, 13 new substances were identified in 2008 (EMCDDA / Europol, 2012, 3), which grew to 74 in 2012 (EMCDDA/Europol, 2013, 5), and 98 in 2015 (EMCDDA, 2016, 30). It is interesting to note that the EU Early Warning System is currently tracking 560 new psychoactive compounds (EMCDDA \& Eurojust, 2016).

In Croatia, the main source of information concerning new psychoactive substances is the Centre for forensic testing, research, and expertise "Ivan Vučetić". The Centre analyses and identifies new psychoactive substances and tests those that have been seized by the police. Additionally, the problem of presence of these substances has been recognized by non-governmental organizations which conduct damage-reduction programs, as they are in immediate contact with drug users and thus have direct information on the phenomenon. Further, in order to get a detailed insight into the use of new psychoactive substances, a series of studies across various target groups was conducted, as mentioned above, which confirm the recreational use of these substances.

In order to enable the implementation of adequate intervention, which Hajer (2003) notes as the third vital element in designing public policy, a national Early-Warning System has been established. The System's first level is that of cooperation between the EMCDA and the Department of National Information Unit for Drugs and Matters of International Cooperation at the Office for Combatting Drug Abuse, which is the coordinator of the Early-Warning System in Croatia and is responsible for coordinating cooperation among the national partners, for further development 
of the System, planning and monitoring the implementation of planned activities, collection and dissemination of information, and reporting to and communicating with the EMCDA. The second level of the system is made up of the Working Group, the members of which are representatives of key national bodies and institutions, non-governmental organizations, and other established experts in the area. The third level consists of the organizational units within each subsystem, and this level is charged with the duty to supply information to the end-users, collect information on the appearance of new psychoactive substances in the field, and reporting on them to the Working Group representative. Finally, the wider network of the System, including media, drug users, other at-risk groups, and the general public are considered the fourth level (Protocol on the Early-Warning System for the appearance of new psychoactive substances, 2007). With all of the above, the information exchange mechanism enables the tracking of implemented activities and represents a basis for a comprehensive assessment of policy implementation based on a variety of data sources (Protocol on the Early-Warning System for the appearance of new psychoactive substances, 2007). The most straightforward example of intervention is that of legal control of new substances. Initially, individual psychoactive substances that posed a public health risk at the national or European level were controlled by means of legislation. However, placing each individual substance on a list of known drugs does not resolve the problem of appearance of new and modified versions of the controlled substances (Huhges and Evans-Brown, 2015). Thus, in January 2016, a generic List of Drugs, Psychotropic Substances and Plants that May Be Processed into Drugs or Used in the Production of Drugs (NN 10/16) was passed, placing entire categories of new psychoactive substances under legal control.

Even though the three preconditions of placing a policy on the agenda, i.e. political decision-making/order, knowledge, and intervention (Hajer, 2003), were all present, the policy of combatting new psychoactive substances is still not recognized as a policy priority in Croatia. In order to better understand the reason for this, we will use the actor-network theory, as it places a particular emphasis on the context in which the structures and processes within a system change (Young, Borland and Coghill, 2010). In the context of the Early Warning System, the scientific evidence, i.e. identification of new psychoactive substances, was made possible by the Centre for forensic testing, research, and expertise "Ivan Vučetić". Further, the Office for Combatting Drug Abuse, as the system coordinator, has from the very start recognized the importance of the problem as an issue of public policy and has worked to network the relevant actors, organized training for various groups of professionals, initiated the placement of new psychoactive substances under legal control, and conceived various activities intended to combat the legal sales of new drugs. The second level of the Early Warning System is that of allies in initiating change, and is based on the two-way information flow and networking among a wider set of professionals who are in direct contact with the consumers of drugs (the third level of the system). With all of the above, cooperation with scientific institutions, implementation of studies on availability and prevalence of new psychoactive substance abuse, and communication with the media enable the gaining of insight into the public opinion on this phenomenon. According to the theory proposed by Young, Borland and Coghill (2010), the process of institutionalizing public policy takes place through three overlapping phases: autonomization of the problem, choice of solution, and approaching the resolution. Autonomization is narrowly tied to the setting of the policy agenda, as it includes information gathering about the relevant phenomenon by means of research and attempts to track 
the phenomenon's various dimensions, discussion among interested actors, media reports on the phenomenon, reporting of political structures concerning the state of the problem, and awareness of the broader community on the dangers posed by new psychoactive substances. The choice of solution includes potential changes in legislation, a generic list of controlled substances, strengthening of other policy implementation mechanisms by means of mobilizing a broader network of actors (e.g. by collecting data from the healthcare system on poisoning and deaths related to new psychoactive substances), and the social acceptance of the activity of tracking and combatting new psychoactive substances. Finally, approaching the solution includes an assessment of public expenditure related to these issues, an increase in awareness of the negative health impact of new drugs, and de-normalizing the abuse of "air fresheners" and "bath salts", mislabeled products that facilitate the sale of new psychoactive substances. The agenda-setting phase predominantly includes the activities in the autonomization phase, while the other phases noted by the actor-network theory are yet to be implemented.

\section{Conclusion}

Public policy can be thought of as a logical sequence of activities undertaken by the creators of public policy so that they may, by means of using various types of instruments, fulfill certain societal goals (Petak, 2008). Fulfilling said goals is always taking place within a certain institutional context and is simultaneously supported through the influence of various ideas on what public policy being implemented in a community ought to be like. In order to more easily understand the logic of policy creation and development, a phase model of policy is often utilized. Such a model was also applied in this paper, with the focus on the first phase of the policy cycle, i.e. agenda-setting or the determining of the policy program. This phase is characterized by the questions relating to the policy initiation phase, or the decision on whether or not a policy will be implemented (Hague, Harrop and Breslin, 2001). In other words, by presenting a certain problem as an important one, the relevant authorities and the broader public are being persuaded of the fact that there is a real problem that demands action (Young and Quinn, 2007).

In the context of the policy of combatting new psychoactive substances in Croatia, it ought to be noted that, even though the strategic elements of this policy have been in place for about ten years, and despite the fact the Early Warning System for new psychoactive substances has been formally in place in Croatia since 2007, the appearance of new psychoactive substances has for years been unable to elicit sufficient interest from the relevant actors. The first research into the use of these substances began in 2011, and only the growing incidence of poisoning/intoxication and death in EU member states that could be linked to new psychoactive substances (EMCDDA, 2014) and the anecdotal reports on such events in Croatia, alongside a growing interest of the media in this phenomenon and the availability of substances in specialized stores (so-called "smart shops") and online, have resulted in an increase in interest in this issue.

Based on the classification put forward by Cobb and Elder (1972, in Howlett, Ramesh, and Perl, 2009), the topic of new psychoactive substances is still at the systemic agenda-setting phase, which mostly consists of the experts' discussions at the different levels of the Early Warning System. This is a manner of shaping policy that sees the defining of policy as primarily the work of experts 
as horizontal actors, i.e. public policy stakeholders who may be able to take part in policy-creation, but are not able to make authoritative decisions. From the point of view of the model, the Croatian case of agenda-setting in the area of combatting new psychoactive substances shows all relevant features of policy that is limited in public visibility (May, 1990), and that is dominated by narrow groups of experts rather than broad sets of actors (Baumgartner and Jones, 1991). Even though there is a gradually appearing need to intensify the efforts and guide the public attention to this phenomenon, the fact that there are numerous other public policy problems in Croatia that are awaiting solution should be taken into account. Further, despite the efforts of the professional support services, the issue of new psychoactive substances is still not able to attract enough attention to be able to transition into the next phase of the public policy cycle, that of policy formulation.

All of this leads us to conclude that the appearance of ne psychoactive substances is not recognized as a serious public policy problem in Croatia. Further development of this important policy depends on the ability of the community to recognize it as a social problem that requires intervention. Besides, its further development may depend on focusing events related to the abuse of new psychoactive substances. Birkland (2013) clearly points out that there are public policy areas in which focusing events are not accompanied by great public attention and that various forms of internal mobilization may place a program or policy on the agenda of political decision-making.

The situation is similar in other EU member states which are using various legal mechanisms (e.g. introducing temporary lists of new psychoactive substances, amending existing legislation on illegal drugs) to affect the transition of this policy into the next phase of the public policy cycle (EMCDDA, 2016). It is possible that a clearer recognition of this policy problem will be affected by the initiative on new regulation of these substances, which was recognized by the Council of the EU as the most effective response to this challenge (Council of the EU, 2016). This initiative consists of enhancing information exchange and risk assessment of new psychoactive substances, and designing responses which are faster and more effective.

The potential for further development of this policy may perhaps be compared to the policy of combatting alcohol abuse, as was prominent in the early 2000s. This is discussed in Esther Versluis, Mendeltje van Keulen and Paul Stephenson's book (2010) on the process of policy-making in the EU. They start from the position that, in order to understand the agenda-setting cycle, one must comparatively understand the workings of three factors that were already discussed in this paper. The first one refers to issue framing of the policy problem, whereby the way in which a question or policy problem is defined. The second factor refers to institutional structures, the policy venue, as strongly noted by Baumgartner and Jones (2009). Finally, the factor of time, or the "policy window" is also important, as the short period in which significant attention is given to an issue, facilitating the decision-making, as noted in the above references to the work of John Kingdon.

If one considers the policy of combatting alcohol abuse as framing of a policy problem, note Versluis et al. (2010), it can be seen that the governments of individual EU member states and NGOs have been trying to place the problem of alcohol abuse on the EU's policy agenda since the mid1990s. However, at that time the issue of alcohol consumption was only seen as a matter related to the free movement of goods, which is the basis of the EU single market policy. Nonetheless, after an ever-greater prominence given to the serious health consequences of alcohol abuse, 
the issue gradually became a social problem that affects public health. In other words, the issue of alcohol abuse was approached through a new frame, one that pointed out the importance of public health, rather than the importance of unfettered functioning of the single European market. This has had two key consequences for the agenda. Instead of the liberalization of the market, the focus was placed on restrictions instead. There was also a simultaneous change of structures that take place in agenda-setting, as the actors interested in market liberalization were supplanted by those interested in matters of public health. There is also the role of another factor: the institutional structures. Here, we refer to a point, an institutional locus that has the authority to reach a decision on a particular matter. Additionally, these institutions are not neutral. Their susceptibility to particular policy proposals is relevant in defining the possibilities of policy. The advocates of limits on alcohol abuse acted on the European Commission's Directorate General for Health and Consumer Protection, and were supported by the World Health Organization. The alcohol manufacturers addressed the Directorate General for the Internal Market, Industry, Entrepreneurship and SMEs. After the frame of understanding for the matter of alcohol was altered, and it became an issue of alcohol as a public bad rather than an issue of free movement of alcoholic goods, the frame and locus of policy-making changed accordingly. What remained was for the third factor - time frame, i.e. window of opportunity to appear. Focusing events are crucial for the appearance of this window, as that is how the attention of policy-makers is placed on a particular issue. The problem of alcoholism among minors became such an important social problem at the time when Sweden took over the EU presidency in 2001. That was the moment when framing, locus of decision-making and the window of opportunity aligned and the policy was placed on the formal policy agenda.

Therefore, it is possible that the further development of policy regarding combatting the abuse of new psychoactive substances will be encouraged by the processes of Europeanization and policy transfer from the European level, should that level engage in policy harmonization across the member states. Until this takes place, the only course of action that remains is that of raising awareness of the negative effects that new psychoactive substances have on public health, endeavoring to garner more attention from the Croatian public. As the extent of this attention strengthens, the odds of appearance of an actor, referred to by Kingdon (1984) as the policy entrepreneur, who would place this issue on the formal policy agenda increases in likelihood.

\section{References}

Baumgartner, F.R., Jones, B.D. (1991): Agenda Dynamics and Policy Subsystems. Journal of Politics. 53 (4). 1044-1074.

Baumgartner, F.R., Jones, B.D. (2009): Agendas and Instability in American Politics, 2nd Ed. Chicago: The University of Chicago Press.

Baumgartner, F.R., Green-Pedersen, C., Jones, B. D. (2006): Comparative studies of policy agendas. Journal of European Public Policy. 13 (7). 959-974. doi:10.1080/13501760600923805

Birkland, T.A., DeYoung, S.E. (2013): Focusing events and policy window. U Araral, E., Fritzen, S., Howlett, M., Ramesh, M., Wu, X. (Ed.), Routledge Handbook of Public Policy. London: Routledge, 175-188.

Cairney, P. (2013): Understanding Public Policy: Theories and Issues. Basingstoke: Palgrave Macmillan. 
Cobb, R., Ross, J.-K., Ross, M.H. (1976): Agenda Building as a Comparative Political Process. The American Political Science Review, 70 (1). 126-138.

Colebatch, H. K. (2004): Policy. Zagreb: Fakultet političkih znanosti.

Colebatch, H.K. (2005): Policy analysis, policy practice and political science. Australian Journal of Public Administration. 64 (3). 14-23. doi: 10.1111/j.1467-8500.2005.00448.x

Council of the European Union (1997): Joint Action concerning the information exchange, risk assessment and control of new synthetic drugs of 16 June 1997, OJ L 167, 25.06.1997.

Council of the European Union (2005): Council Decision 2005/387/JHA of 10 May 2005 on the Information Exchange, Risk-Assessment and Control of New Psychoactive Substances, OJ L 127, 20.05.2005.

Council of the European Union (2016): Council adopts its position on the reform of the new psychoactive substances regislation. Press release 730/16, 08/12/2016. http://WwW. consilium.europa.eu/en/press/press-releases/2016/12/08-psychoactive-substances/ (Accessed on 17/1/2017.)

Dearing, J.W., Rogers, E.M. (1996): Agenda-Setting. Thousand Oaks: Sage.

Doležal, D. (2012): Prikaz rezultata projekta Distribucija i cijena ilegalnih droga u RH [An overview of the project Distribution and Price of Illegal Drugs in Croatia], In: Milković, M., Doležal, D., Hržica, G., Stošić, J. (Ed.s), Istraživanja u edukacijsko-rehabilitacijskim znanostima. [Research in Education and Rehabilitation Sciences] Presented at the 8th international conference on research in education and rehabilitation sciences, 27-29 September 2012. Zagreb: Sveučilište u Zagrebu, 83.

Downs, A. (1972): Up and Down with Ecology-the Issue-Attention Cycle. Public Interest. 28, 38-50.

European Commission (2014): Flash Eurobarometer. Young people and drugs. Report. Flash Eurobarometer 401 - TNS Political \& Social. http://ec.europa.eu/public_opinion/flash/ fl_401_en.pdf (Accessed on 20/1/2017.)

European Monitoring Centre for Drugs and Drug Addiction (EMCDDA) (2007): Early-Warning System on New Psychoactive Substances. Operating Guidelines. Luxembourg: Office for Official Publications of the European Communities.

European Monitoring Centre for Drugs and Drug Addiction (EMCDDA) (2014): European Drug Report - Trends and Developments 2014. Luxembourg: Publications Office of the European Union. doi:10.2810/32890

European Monitoring Centre for Drugs and Drug Addiction (EMCDDA) (2016): European Drug Report: Trends and Developments. European Monitoring Centre for Drugs and Drug Addiction. Luxembourg: Publications Office of the European Union.

EMCDDA / Europol (2012): EMCDDA / Europol 2011 Annual Report on the Implementation of Council Decision 2005/387/JHA. Luxembourg: Publications Office of the European Union.

EMCDDA / Europol (2013): New Drugs in Europe, 2012. EMCDDA / Europol 2012 Annual Report on the Implementation of Council Decision 2005/387/JHA. Luxembourg: Publications Office of the European Union. doi:10.2810/99367

European Monitoring Centre for Drugs and Drug Addiction and Eurojust (2016): New psychoactive substances in Europe: Legislation and prosecution — current challenges and solutions. EMCDDA-Eurojust joint publication. Luxembourg: Publications Office of the European Union. doi:10.2810/777512 
Glavak Tkalić, R., Miletić, G-M., Maričić, J. (2016): Uporaba sredstava ovisnosti u hrvatskom društvu: Istraživanje na općoj populaciji [Substance abuse in Croatian society: research in the general population]. Zagreb: Institut društvenih znanosti Ivo Pilar i Ured za suzbijanje zlouporabe droga Vlade Republike Hrvatske.

Grdešić, I. (1995): Političko odlučivanje [Political decision-making]. Zagreb: Alinea.

Green-Pedersen, C., Mortensen, P.B. (2013): Policy agenda-setting studies: Attention, politics and the public. In Araral, E., Fritzen, S., Howlett, M., Ramesh, M., Wu, X. (Eds.), Routledge Handbook of Public Policy. London: Routledge, 167-174.

Hague, R., Harrop M., Breslin S. (2001): Komparativna vladavina i politika [Comparative government and politics]. Zagreb: Fakultet političkih znanosti.

Hajer, M. (2003): Policy without polity? Policy analysis and the institutional void. Policy Sciences, 36. 175-195.

Hill, M. (2010): Proces stvaranja javnih politika [The policy-making process]. Zagreb: Fakultet političkih znanosti.

Hogwood, B., Gunn, L.A. (1984): Policy Analysis for the Real World. Oxford: Oxford University Press.

Howlett, M., Ramesh, M., Perl, A. (2009): Studying Public Policy - Policy Cycles \& Policy Subsystems. Third Edition. Toronto: Oxford University Press.

Huhges, B., Ewans-Brown, M. (2015): New psychoactive substances in Europe. Innovative legal responses. EMCDDA. Luxembourg: Publications Office of the European Union. doi:10.2810/90544

Jerković, D. (2015): Samoodređenost studenata u studenskim naseljima i učestalost konzumiranja alkohola i kanabinoida [Self-determination of students in university housing and the frequency of alcohol and cannabinoid consumption], PhD thesis. Edukacijsko-rehabilitacijski fakultet Sveučilišta u Zagrebu.

Jerković, D. (2016): Izazovi novih psihoaktivnih tvari. [The challenge of new psychoactive substances], in D. Roviš (Ed.), Izazovi izgradnje cjelovitog pristupa prevenciji ovisnosti te liječenju, resocijalizaciji i socijalnoj reintegraciji ovisnika u Republici Hrvatskoj - Analiza stanja i potreba te iskustava Primorsko-goranske županije. [The challenges of building an integrated approach to prevention of addiction, treatment, resocialization, and social integration of addicts in the Republic of Croatia - Analysis of the current state and needs, and the experiences in Primorje - Gorski Kotar County], Rijeka: Medicinski fakultet Sveučilišta u Rijeci i Nastavni zavod za javno zdravstvo Primorsko-goranske županije, 33-44.

John, P. (1998): Analysing Public Policy. London: Pinter.

Jones, B.D., Baumgartner, F.R. (2005): The Politics of Attention. How Government Prioritizes Problems. Chicago: The University of Chicago Press.

Jones, B.D., Baumgartner, F.R. (2012): From There to Here: Punctuated Equilibrium to the General Punctuation Thesis to a Government Information Processing. Policy Studies Journal. 40 (1). 1-19.

Kingdon, J. W. (1984): Agendas, Alternatives and Public Policies. Boston: Little, Brown \& Company.

Kovčo Vukadin, I. (2014): Ispitivanje kvalitete života studenata u Republici Hrvatskoj. Istraživačko izvješće. [Testing the quality of life among students in the Republic of Croatia - research brief], https://drogeiovisnosti.gov.hr/o-uredu/djelokrug/ovisnosti-i-vezane-teme/droge- 
i-ovisnost/publikacije/istrazivanja/istrazivanje-kvalitete-zivota-studenata-erf-2014/1071 (Accessed on 10/2/2017.)

Kranželić, V., Jerković, D. (2012): Istraživanja novih trendova u konzumiranju sredstava ovisnosti - iskustva i rezultati on-line pilot istraživanja [Researching new trends in substance abuse - experiences and results of the online pilot-study], In: Milković, M., Doležal, D., Hržica, G., Stošić, J. (Eds.), Istraživanja u edukacijsko-rehabilitacijskim znanostima. [Research in Education and Rehabilitation Sciences] Presented at the 8th international conference on research in education and rehabilitation sciences, 27-29 September 2012. Zagreb: Sveučilište u Zagrebu, 83-84.

Kranželić, V., Doležal, D. (2013): Online istraživanje pojavnosti novih droga u Republici Hrvatskoj. [Online study on the incidence of new illegal drugs in the Republic of Croatia] https:// drogeiovisnosti.gov.hr/UserDocs/mages/uredarhiva/2013/11/2013_novi_trendovi.pdf (Accessed 14/2/2017.)

Kraus, L., Guttormsson, U., Leifman, H., Arpa, S., Molinaro, S., Monshouwer, K. et al. (2016): ESPAD Report 2015: Results from the European School Survey Project on Alcohol and Other Drugs. European Monitoring Centre for Drugs and Drug Addiction \& The European School Survey Project on Alcohol and Other Drugs. Luxembourg: Publications Office of the European Union.

Kustec Lipicer, S. (2012): Vrednovanje javnih politika. [Evaluating public policy] Zagreb: Disput.

May, P.J. (1990): Reconsidering Policy Design: Policies and Publics. Journal of Public Policy 11 (2). 187-206.

Mazmanian, D. A., Sabatier, P. A. (1980): A Multivariate Model of Public Policy-Making.

Nacionalna strategija suzbijanja zlouporabe (opojnih) droga u Republici Hrvatskoj za razdoblje 2006.-2012 [National strategy for preventing drug abuse in the Republic of Croatia for 2006 -2012], Narodne novine 147/2005.

Nacionalna strategija suzbijanja zlouporabe droga u Republici Hrvatskoj za razdoblje 2012.-2017 [National strategy for preventing drug abuse in the Republic of Croatia for 2012 -2017], Narodne novine 122/2012.

Petak, Z. (2007): Javne politike: razvoj discipline u Hrvatskoj i svijetu. [Public policy: the development of the discipline in Croatia and the world], In: Kasapović, M. (Ed.), Izlazak iz množine? Stanje hrvatske političke znanosti. [Departing the plural? The state of political science in Croatia] Zagreb: Fakultet političkih znanosti, 187-215.

Petak, Z. (2008): Dimenzije javnih politika i javno upravljanje. [Dimensions of public policy and public administration] Politička misao. 45 (2). 9-26.

Petek, A. (2012): Transformacija politike prema osobama s invaliditetom: primjena policy mreža. [Transformation of policy towards disabled persons: application of policy networks] PhD thesis. Zagreb: Fakultet političkih znanosti. https://bib.irb.hr/datoteka/568532. Doktorat_AP__ final.pdf (Pristupljeno 10.2.2017.)

Petek, A. (2014): Dnevni red. [Policy agenda] In: Petek, A., Petković, K. (Eds.), Pojmovnik javnih politika [Concepts in public policy]. Zagreb: Fakultet političkih znanosti, 54-55.

Popis droga, psihotropnih tvari i biljaka iz kojih se može dobiti droga te tvari koje se mogu uporabiti za izradu droga [List of Drugs, Psychotroopic Substances and Plants that May Be Processed into Drugs or Used in the Production of Drugs]. Narodne novine, 10/2016.

Princen, S. (2009): Agenda-Setting in the European Union. Basingstoke: Palgrave Macmillan. 
Protokol o Sustavu ranog upozoravanja u slučaju pojave novih psihoaktivnih tvari u Republici Hrvatskoj. Vlada Republike Hrvatske [Protocol on the Early-Warning System for the appearance of new psychoactive substances], 02. studenog 2007.

Sabatier, P.A., Jenkins-Smith, H.C. (1993): Policy Change and Learning: An Advocacy Coalition Framework. Boulder: Westview Press.

Schneider, A., Ingram, H. (1993): Social Construction of Target populations: Implications and Policy. American Political Science Review 87 (2). 334-347.

Sharp, E.B. (1992): Agenda-Setting and Policy Results: Lessons From Three Drug Policy Episodes. Policy Studies Journal 20 (4). 538-551.

Stone, D. (2012): Policy Paradox: The Art of Political Decision-Making. New York: W.W. Norton \& Company.

United Nations Office on Drugs and Crime (UNODC) (2015): World Drug Report. New York: United Nations.

Uredba o osnivanju Ureda za suzbijanje zlouporabe opojnih droga, Narodne novine [Regulation on Founding of the Office for Combatting Drug Abuse] 18/2002, 12/2005, 111/2006, 19/2010, 36/2012, 130/2012.

Ustav Republike Hrvatske [Constitution of the Republic of Croatia], Narodne novine 56/1990, 135/1997, 113/2000, 28/2001, 76/2010, 5/2014.

Versluis, E., van Keulen, M., Stephenson, P. (2010): Analyzing the European Union Policy Process. Basingstoke: Palgrave Macmillan.

Young, D., Borland, R., Coghill, K. (2010): An Actor-Network Theory Analysis of Polcy Innovation for Smoke-Free Places: Understanding Change in Complex Systems. American Journal of Public Health. 100 (7). 1208-1217.

Young, E., Quinn, L. (2007): Pisanje djelotvornih prijedloga za javne politike: vodič za policy savjetnike u zemljama Srednje i Istočne Europe [Writing effective policy proposals: guide for policy consultants in Central and Eastern Europe]. Zagreb: DIM.

Zakon o potvrđivanju Sporazuma između Republike Hrvatske i Europske unije o sudjelovanju Republike Hrvatske u radu Europskog centru za praćenje droga i ovisnosti o drogama, [Act on confirming the Agreement between the Republic of Croatia and the European Union on the participation of the Republic of Croatia in the work of the European Monitoring Centre for Drugs and Drug Addiction], NN 03/2013, International agreements.

Zakon o suzbijanju zlouporabe (opojnih) droga [Combatting Drug Abuse Act], Narodne novine, br. 107/2001, 87/2002, 163/2003, 141/2004, 40/2007, 149/2009, 84/2011. 